\title{
Epidemiological profile of blood donors diagnosed with syphilis in the State of Piauí, Northeastern Brazil
}

\section{Aline Cristina Figueiredo Lima ${ }^{1}$, Joaquim Nylson Santos Silva ${ }^{1}$, Roseane Mara Cardoso Lima Verde ${ }^{2}$, Matheus Hipólito do Nascimento ${ }^{3}$, Joacilda da Conceição Nunes $^{4}$, Leonardo Ferreira Soares $^{5}$ and Evaldo Hipólito de Oliveira ${ }^{6}$}

\footnotetext{
${ }^{1}$ Faculdade Santo Agostinho. Av. Valter Alencar, 665. São Pedro. Teresina-PI. Brazil (CEP 64049-550).

${ }^{2}$ Secretaria de Estado da Saúde do Piauí. Maternidade Dona Evangelina Rosa. Av. Higino Cunha, 1552. Ilhotas. Teresina-PI. Brazil (CEP 64014-220).

${ }^{3}$ Faculdade de Odontologia. Centro Universitário Unieuro. Setor de Clubes Esportivos Sul, Trecho 0, Conjunto 05. Asa Sul. Brasília-DF (CEP 70200-001).

${ }^{4}$ Universidade Federal da Paraíba. Centro de Ciências Médicas. Departamento de Pediatria e Genética. Campus I. João Pessoa-PB. Brazil. (CEP 58051-900).

${ }^{5}$ Centro de Ciências Biológicas, Sociais e Aplicadas. Universidade Estadual da Paraíba. Rua Baraúnas, 351. Cristo Redentor. João Pessoa-PB. Brazil. (CEP 58429$500)$.

6Universidade Federal do Piauí. Centro de Ciências da Saúde. Campus Universitário Ministro Petrônio Portella. Bairro Ininga. Teresina-PI. Brazil (CEP 64049-550). Email: evaldohipolito@gmail.com.
}

\begin{abstract}
Syphilis is a sexually transmitted disease caused by Treponema pallidum. In the State of Piauí, Northeastern Brazil, the units of the Hematology and Hemotherapy Center of Piaui (HEMOPI) receive blood donations to maintain the stock of blood and its derivatives. This study aimed to obtain epidemiological data on the frequency of syphilis in blood donors in the State of Piauí, from 2008 to 2013. This is a descriptive retrospective research based on secondary data with quantitative and exploratory analysis, in which the variables age, gender, school level, marital status, occupation, and municipality where the participants reside were recorded, analyzing the prevalence of syphilis in donors. A total of 233,927 volunteer donations were considered, of which 4,118 were positive for syphilis. The prevalence $(1.76 \%)$ was analyzed using the ELISA technique, and it was relatively low among blood donations in comparison to other states. The most frequent donations were made by students in the Municipality of Teresina, downtown, and there was a statistically significant association for men, age group of 40-49 years, incomplete elementary school and married marital status. Therefore, it was concluded that the prevalence of syphilis in the State of Piaui is lower than in other
\end{abstract}

Received January 26, 2018

Accepted

March 10, 2018

Released

April 30, 2018

Full Text Article

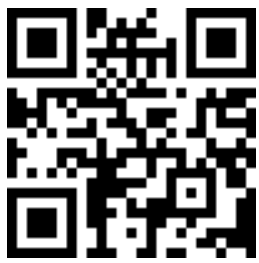


states and that updated epidemiological data on the presence of syphilis in blood samples from blood donors has been generated.

Keywords: Blood bank; Blood donors; Syphilis; Epidemiology.

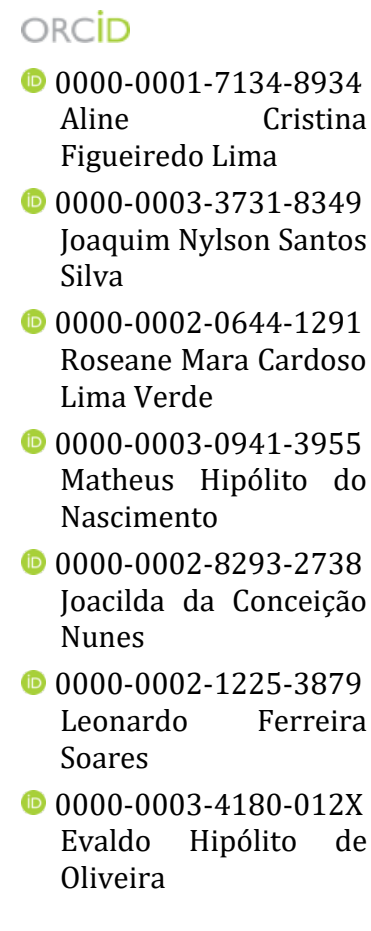

Afterward, there is hematogenous dissemination of the treponema with the appearance of general signs such as adenopathies and exanthema, which can last up to eight weeks (secondary syphilis). In one to two years, the disease evolution may lead to cardiovascular and neurological complications and gums (tertiary syphilis). Tertiary syphilis may have an incubation period of up to 40 years. Some individuals, due to an immunological barrier or inappropriate antibiotic treatments, develop a latent form of the disease and remain asymptomatic for many years, maintaining a transmissibility potential (Galatoire et al., 2012).

The detection of syphilis in blood centers is performed through nontreponemal and treponemal tests. VDRL is the commonly used non-treponemal test, which is based on flocculation on blade and evaluation of the disease by known titration, with a diagnostic positivity of $75 \%$ for primary syphilis. The disease is confirmed by treponemal test, generally using the ELISA test, which has 85\% specificity (São Paulo, 2012b). 
In congenital syphilis, when the infected mother is treated before the $16^{\text {th }}$ gestational week, the fetus infection can be prevented. If the treatment started after the 18th week, it can no longer prevent the irreversible neural deafness, interstitial keratitis, and bone and joint changes in newborns, even if the disease can be cured. The fetus will be at higher risk if the mother has the disease for less than two years, and the infected baby can develop condyloma and boils up to the first year of life (Habif, 2012).

In Brazil, the Ordinance No. $1376 / 1993$, of the Ministry of Health (Brasil, 1993), supported by Resolution RDC No. 343/2002, of the National Health Surveillance Agency (ANVISA) (Brasil, 2002), determined the mandatory serological screening tests in hemotherapy services for syphilis, Chagas disease, hepatitis B and C, AIDS, HTLV, and malaria (Oliveira et al., 2008).

Piauí State ranks fourth in cases of live births with syphilis in Brazil, behind the states of Acre, Rondônia, and Roraima, probably due to the underreporting and lack of access to health services in these states. The same can be observed in cases of congenital syphilis in children under one year of age (Brasil, 2012a).

Thus, as a sequence of previous studies (Silva et al., 2017), this research aimed to analyze the epidemiological profile of blood donors diagnosed with syphilis in the Hematology and Hemotherapy Center of Piauí (HEMOPI) and determine the prevalence of syphilis in the donor population, recording the socioeconomic variables of infected donors, such as age, gender, skin color, school level, marital status and occupation.

\section{Methods}

This is a descriptive, retrospective and exploratory study based on secondary data and quantitative analysis. Information from people who donated blood in the
HEMOVIDA database of the Hematology and Hemotherapy Center of Piauí (HEMOPI), from January 2008 to December 2013, was collected. The sample comprised 233,927 individuals. The variables gender, age, ethnicity, school level, marital status, occupation, and municipality and neighborhood where the donors lived in were analyzed, both in reactive and non-reactive donors for syphilis. After donation, serological screening tests were performed, as recommended by Resolution RDC No. 343/2002 (Brasil, 2002), using the ELISA technique. When the result was positive for syphilis, it was then confirmed by treponemal test. If the infection was confirmed, the blood bag was discarded, and the donor register was updated, indicating the presence of the disease in such individual.

Data were analyzed and organized based on prevalent characteristics both of donors diagnosed and non-diagnosed with syphilis. Data processing was carried out by using the SPSS, version 19.1, and the data were presented in tables and graphs. The chisquare test $\left(\chi^{2}\right)$ was used to compare the risk factors between sufferers and nonsufferers of syphilis; then, a significance level lower than 5\% $(\mathrm{p}<0.05)$ was established, with a 95\% CI.

This research was approved by the Ethics Committee on Research with Human Beings of Santo Agostinho University (Protocol CAAE No. 31747414.0.0000.5602) and met the requirements described in the Resolution No. 466/2012 of the National Health Council (Brasil, 2012b).

\section{Results and discussion}

After data analysis, it was found a population of 233,927 blood donors in Piauí State, from 2008 to 2013. The mean age was 32 years, with a standard deviation of 10.46, and a minimum age of 16 years and a maximum one of 69 years. After syphilis screening, a total of 4,188 infected people was identified (1.76\%). 
Table 1. Blood donation frequency in the Hematology and Hemotherapy Center of Piauí State (HEMOPI).

\begin{tabular}{lcc}
\hline \multirow{2}{*}{ Year of donation } & \multicolumn{2}{c}{ Frequency } \\
\cline { 2 - 3 } & No. & $\mathbf{\%}$ \\
\hline 2008 & 36,213 & 15.5 \\
2009 & 38,444 & 16.4 \\
2010 & 35,323 & 15.1 \\
2011 & 39,015 & 16.7 \\
2012 & 41,173 & 17.6 \\
2013 & 43,759 & 18.7 \\
\hline Total & $\mathbf{2 3 3 , 9 2 7}$ & $\mathbf{1 0 0 . 0}$ \\
\hline
\end{tabular}

The frequency of donations throughout the study period was obtained and the percentages of donations year-to-year and their distribution during such period were determined (Table 1).

There was an increase in the number of donations from 2011 to 2013 , and the last year accounted for 43,759 donations (Table 1). This fact can be explained by the intensification of blood donation campaigns, such as collections carried out in schools, universities and public institutions, and on commemorative days, and awareness campaigns on the importance of blood donation, among other initiatives, resulting in the increase in the number of diagnosis of infectious diseases (Oliveira et al., 2015).

Regarding the blood donation rates, Piauí State stands out in comparison to Goiás State, for example. The Hematology and Hemotherapy Center of Goiás (HEMOGO) accounted for $27,292,30,018,34,955$ and 34,207 blood donations, from 2008 to 2011, respectively (Rodrigues, 2012).

Table 2. Syphilis frequency in blood donor's population in the Hematology and Hemotherapy Center of Piauí State (HEMOPI).

\begin{tabular}{lcc}
\hline \multirow{2}{*}{ Results } & \multicolumn{2}{c}{ Frequency } \\
\cline { 2 - 3 } & No. & $\%$ \\
\hline Reactive & 4,118 & 1.76 \\
Non-reactive & 229,809 & 98.24 \\
\hline Total & $\mathbf{2 3 3 , 9 2 7}$ & $\mathbf{1 0 0 . 0 0}$ \\
\hline
\end{tabular}

The analysis of the data from the Hematology and Hemotherapy Center of Piauí (HEMOPI) indicated a syphilis seroprevalence of $1.76 \%$, which is a relatively low rate, compared to those of $4.1 \%$ and $2.1 \%$, reported by Andrade et al. (1989) and Oliveira et al. (2008), respectively. However, other studies pointed out values lower than those found in this study, such as Almeida-Neto et al. (2009) and Rodrigues (2012), who found values of $0.32 \%$ and $0.61 \%$, respectively.
Regarding gender, the number of positive sample for syphilis in the volunteer blood donor population is shown in Table 3.

As can be observed in Table 3, the number of positive cases in men, with statistical significance $(p<0.001)$, is much higher than in women. Similar studies, one carried out in an STD/HIV Screening Center and another in a Blood Center, both in São Paulo State, also pointed out the preponderance of 
Table 3. Gender distribution of volunteer blood donors reactive and non-reactive for syphilis in the Hematology and Hemotherapy Center of Piauí State (HEMOPI).

\begin{tabular}{lcccc}
\hline \multirow{2}{*}{ Gender } & \multicolumn{2}{c}{ Syphilis } & \multirow{2}{*}{ Total } & \multirow{2}{*}{$\%$} \\
\cline { 2 - 3 } & Reactive & Non-reactive & & \multirow{2}{*}{33.3} \\
\hline Female & 1,371 & 84,432 & 85,803 & 66.7 \\
Male & 2,747 & 145,377 & 148,124 & $\mathbf{1 0 0 . 0}$ \\
\hline Total & $\mathbf{4 , 1 1 8}$ & $\mathbf{2 2 9 , 8 0 9}$ & $\mathbf{2 3 3 , 9 2 7}$ &
\end{tabular}

In order to evaluate the age of blood donors (Table 4), the sample was divided into age groups: under 17, 18-19, $30-39,40-49$, and over 50 years old. The first $(0.5 \%)$ and the last $(14.2 \%)$ groups had the lowest seropositivity rates since the first one was comprised of minors who needed parental consent and the second one of people with low sexual activity. Regarding the last one, in addition to the low sexual activity, the small number of donors over 50 years old is another fact to be considered (Pinto, 2012).

Table 4. Age distribution of volunteer blood donors diagnosed with syphilis in the Hematology and Hemotherapy Center of Piauí State (HEMOPI).

\begin{tabular}{|c|c|c|c|}
\hline \multirow{2}{*}{ Age group } & \multicolumn{2}{|c|}{ Syphilis } & \multirow{2}{*}{ Total } \\
\hline & Reactive & Non-reactive & \\
\hline$<17$ & 4 & 903 & 907 \\
\hline $18-29$ & 879 & 112,004 & 112,883 \\
\hline $30-39$ & 1,097 & 63,200 & 64,297 \\
\hline $40-49$ & 1,248 & 35,686 & 36,934 \\
\hline$>50$ & 890 & 18,016 & 18,906 \\
\hline Total & 4,118 & 229,809 & 233,927 \\
\hline
\end{tabular}

The distribution of the disease among individuals older than 16 years, considering age and presence of syphilis in blood donors, is shown in Table 4.

The most expressive number of cases was found in donors aged 40-49 years, with a relative statistical significance $(p<0.001)$, followed by the 30-39 years group. A study carried out by Almeida-Neto (2007) in the Paulista Blood Center showed a similar age group, in which the highest number of syphilis cases were diagnosed in the age group ranging from 41 to 50 years old, followed by the $31-40$ age group.

In summary, according to the evaluation of the serological profile of blood donors, most of the donations $(43,759)$ were made in 2013 (Table 1), the prevalence of syphilis in such donors was $1.76 \%(4,188)$ (Table 2), and the highest number of donations and syphilis positivity was observed in men ( $\mathrm{p}<$ 0.001 ) (Table 3). The 40-49 age group had the highest number $(1,248$ donors $)$ of seropositivity for syphilis ( $p=0.001$ ) (Table 4), which, among other reasons, is related to a sexual activity peak, since sexual relationship, especially the unprotected one, is one of the main transmission pathways of syphilis, which can also be transmitted by the contact with mucocutaneous lesions with positive treponemal, or by contaminated blood transfusion, in addition to the transplacental route (Santos and Anjos, 2009).

School level was also evaluated; this epidemiological indicator was divided into seven groups (Table 5). 
Table 5. School level of syphilis sufferers identified in blood donation screening in the Hematology and Hemotherapy Center of Piauí (HEMOPI).

\begin{tabular}{lrcc}
\hline \multirow{2}{*}{ School level } & \multicolumn{2}{c}{ Syphilis } & \multirow{2}{*}{ Total } \\
\cline { 2 - 3 } & Reactive & Non-reactive & \\
\hline Not reported & 30 & 1,215 & 1,245 \\
Non-alphabetized & 88 & 2,166 & 2,254 \\
Incomplete Elementary School & 1,574 & 47,963 & 49,537 \\
Complete Elementary School & 433 & 16,138 & 16,571 \\
Incomplete high school & 349 & 23,644 & 23,993 \\
Complete high school & 1,162 & 85,328 & 86,490 \\
Incomplete higher education & 267 & 34,706 & 34,973 \\
Complete higher education & 215 & 18,649 & 18,864 \\
\hline Total & $\mathbf{4 , 1 1 8}$ & $\mathbf{2 2 9 , 8 0 9}$ & $\mathbf{2 3 3 , 9 2 7}$ \\
\hline p $<0.001$ & & &
\end{tabular}

The school-level influenced the number of syphilis infections, as the group with incomplete elementary school had the highest number of infected individuals $(\mathrm{p}<0.001)$. Nevertheless, it is worth mentioning that syphilis was also detected even in the group with higher education, which evidences that the use of knowledge for personal benefit is still neglected since the group with complete high school was the second one with the highest number of cases.

Knowledge about sexually transmitted diseases is usually taught by science teachers in the 7 th grade of elementary school, being a topic of the human body study. However, such knowledge seems to be disorganized or insufficient, according to the teenagers' knowledge of the transmission pathways of syphilis. Forty-eight percent of the girls and only $28 \%$ of the boys reported vaginal sex as a transmission pathway, and the most alarming fact is the number of individuals without information on this issue: $34 \%$ of the girls and $45 \%$ of the boys (Brêtas et al. 2009).

Regarding the marital status (Table 6), the volunteer blood donors, subjected to the screening process, were divided into the following groups: single, married, widowed, separated, divorced, estranged, and others. The highest number of seropositivity was identified in married donors $(2,207$ cases $)$ ( $p=0.001$ ), corresponding to $53.59 \%$ of the sample, with statistically significant data; therefore, they showed a higher risk of infection by Treponema. On the other hand, single donors were less likely to develop the disease. The lack of condoms at the time of having sex and the lack of information and orientation were the main reasons, reported by men, for not using condom in sexual relationships, whereas trust in the partner was the main argument reported by women (Pereira, 2009).

With regards to skin color, the ethnicity distribution of the study population is shown in Table 7. The donors' ethnicity was characteristic in the present study according to the skin color, as follows: 1) Caucasian, 2) Brazilian Caucasian, 3) Black, 4) Yellow, 5) Indigenous, and 6) Mestizo. The Mestizo group had the highest number of seropositivity for syphilis $(2,977$ infected donors), with statistically significant data ( $p<0.001$ ), corresponding to $79.29 \%$ of the positive cases. This ethnic group is the most common in the northeast region of Brazil and in the State of Piauí, and it is represented by people who donated the highest amount of blood during the study period. 
Table 6. Sample distribution regarding marital status.

\begin{tabular}{|c|c|c|c|}
\hline \multirow{2}{*}{ Marital Status } & \multicolumn{2}{|c|}{ Syphilis } & \multirow{2}{*}{ Total } \\
\hline & Reactive & Non-reactive & \\
\hline Not reported & 26 & 1,070 & 1,096 \\
\hline Single & 1,684 & 135,586 & 137,270 \\
\hline Married & 2,207 & 87,278 & 89,485 \\
\hline Widowed & 60 & 1,368 & 1,428 \\
\hline Separated & 10 & 320 & 330 \\
\hline Divorced & 71 & 2,038 & 2,109 \\
\hline Estranged & 38 & 945 & 983 \\
\hline Others & 22 & 1,204 & 1,226 \\
\hline Total & 4,118 & 229,809 & 233,927 \\
\hline
\end{tabular}

There was a higher number of positive cases of syphilis in self-declared mestizos, followed by Caucasians, whereas indigenous had a lower incidence of syphilis. Lins (2014) also found a high percentage $(74.42 \%)$ of syphilis in brown-skinned pregnant women (mestizos) in the Nossa Senhora de Nazaré Maternal-Child Hospital
(HMINSN), in the Municipality of Boa Vista, Roraima State, Brazil, from 2008 to 2011. However, when only indigenous ethnicity was studied, a high incidence of syphilis was diagnosed, as reported by Tiago et al. (2017), who analyzed data from the Special Indigenous Sanitary District of Mato Grosso do Sul (DSEI-MS), from 2011 to 2014.

Table 7. Ethnic distribution of volunteer blood donors in the Hematology and Hemotherapy Center of Piauí State (HEMOPI).

\begin{tabular}{lccc}
\hline \multirow{2}{*}{ Ethnicity } & \multicolumn{2}{c}{ Syphilis } & \multirow{2}{*}{ Total } \\
\cline { 2 - 3 } & Reactive & Non-reactive & 10,554 \\
Not reported & 160 & 10,394 & 23,831 \\
Caucasian & 707 & 23,124 & 9,311 \\
Brazilian Caucasian & 195 & 9,116 & 2,760 \\
Black & 51 & 2,709 & 290 \\
Yellow & 9 & 281 & 1,212 \\
Indigenous & 19 & 1,193 & 185,969 \\
Mestizo & 2,977 & 182,992 & $\mathbf{2 3 3 , 9 2 7}$ \\
\hline Total & $\mathbf{4 , 1 1 8}$ & $\mathbf{2 2 9 , 8 0 9}$ &
\end{tabular}

The distribution of volunteer blood donors diagnosed with syphilis in the ten largest municipalities of the State of Piauí is shown in Table 8.

Teresina accounted for more than a half of the positive blood samples (53\% of cases) obtained from the Blood Center of Piauí, followed by Parnaíba (8.8\%) and Timon (5.9\%), which is a municipality belonging to Maranhão State, but surrounding Teresina. 
Table 8. Geographic distribution of volunteer blood donors diagnosed with syphilis in the Hematology and Hemotherapy Center of Piauí State (HEMOPI).

\begin{tabular}{lcc}
\hline Municipalities* $^{*}$ & Number & \% \\
\hline Altos & 48 & 1.2 \\
Barras & 32 & 0.8 \\
Campo Maior & 69 & 1.7 \\
Caxias & 41 & 1.0 \\
Floriano & 113 & 2.7 \\
Parnaíba & 363 & 8.8 \\
Picos & 126 & 3.1 \\
Teresina & 2,181 & 5.3 \\
Timon & 243 & 5.9 \\
Piripiri & 32 & 0.8 \\
\hline
\end{tabular}

*The ten municipalities where the highest number of syphilis cases were detected.

The percentage of territorial distribution of volunteer blood donors, diagnosed with syphilis in the ten neighborhoods of Teresina, where the highest number of cases were reported, is shown in Table 9.

Table 9. Distribution of volunteer blood donors diagnosed with syphilis in Teresina in the Hematology and Hemotherapy Center of Piauí State (HEMOPI), from 2008 to 2013.

\begin{tabular}{lcc}
\hline Neighborhood* & Number & \% \\
\hline Downtown & 409 & 9.9 \\
Dirceu I & 41 & 1.0 \\
Dirceu II & 38 & 0.9 \\
Lourival Parente & 37 & 0.8 \\
Matadouro & 34 & 0.8 \\
Mocambinho & 40 & 1.0 \\
Monte Castelo & 43 & 1.0 \\
Santo Antônio km 07 & 53 & 1.2 \\
São José & 38 & 0.9 \\
Rural Area & 115 & 2.8 \\
\hline
\end{tabular}

* The ten neighborhoods in Teresina with the highest number of confirmed cases.

Professional occupation of the blood donors diagnosed with syphilis in Piauí State is shown in Table 10.

It is important to highlight the high number of cases diagnosed among students since they, even with more information, this group had the highest syphilis prevalence.

In Brazil, serological test in donor screening to detect pathologies is mandatory if there is no specification regarding the type of test to be carried out (treponemal or non-treponemal) as reported by Brasil (2004). The majority of hemotherapy services use a nontreponemal test, the VDRL or RPR, due to two reasons: the lowest cost and the lowest rate of bag discard (Sáez-Alquézar et al., 2007).

The treponemal infection starts almost imperceptibly, as treponemas invade the body and stay there in an imperceptible way, and such initial phase is highly contagious. When the infection develops, it infects the organism abruptly into secondary syphilis, causing rashes, which the body tries to eliminate throughout the skin. The third stage of this pathology is detectable by the manifestation of signs and symptoms, causing lesions in the brain, heart, blood vessels, liver, and kidneys. Until it 
reaches its most developed stage (quaternary), it causes cerebral and spinal cord degeneration, it suppresses sensory capability and establishes the inability to write, speak and even think (Mohana, 2002).

Table 10. Occupation of blood donors diagnosed with syphilis in the Hematology and Hemotherapy Center of Piauí State (HEMOPI), from 2008 to 2013.

\begin{tabular}{lcc}
\hline Occupation* & Number & \% \\
\hline Freelance & 117 & 2.8 \\
Merchant & 116 & 2.8 \\
Homemaker & 200 & 4.9 \\
Domestic & 103 & 2.5 \\
Student & 402 & 9.8 \\
Farmer & 181 & 4.4 \\
Military & 159 & 3.9 \\
Driver & 180 & 4.4 \\
Bricklayer & 120 & 2.9 \\
Salesman & 68 & 1.7 \\
\hline
\end{tabular}

* The ten most frequent occupations among blood donors diagnosed with syphilis.

In general, once introduced into the body, the treponema spreads to it without causing lesions, which takes from 9 to 90 days, with an average of 21 days to develop the chancre at the entry point. Treponema will influence in the production of non-treponemal antibodies and specific treponemal antibodies and antigens; thus, the antibodies will provide a diagnosis of the disease (Kumar et al., 2008).

\section{Conclusion}

The results obtained in this study characterizes the epidemiological profile of blood donors in the Hematology and Hemotherapy Center of Piauí (HEMOPI), who had a relatively low prevalence of syphilis $(1.76 \%)$ from 2008 to 2013 . The most frequent donations occurred in Teresina, downtown, and there was a statistically significant association for males, between 40 and 49 years old, incomplete elementary school, and married marital status. The intensification of measures such as health campaigns, such as those proposed by Bonney (2015) for neglected diseases carried out to inform the population about the disease and its prevention, as well as to encourage the adoption of safe sex practices, may contribute to a further reduction of this rate.

\section{Conflict of interest statement}

Authors declare that they have no conflict of interests.

\section{References}

Almeida-Neto, C. Perfil epidemiológico de doadores de sangue com diagnóstico sorológico de sífilis e HIV. São Paulo: USP, 2007. (Thesis).

Almeida-Neto, C.; Murphy, E. L. Profile of blood donors with serologic tests reactive for the presence of syphilis in São Paulo, Brazil. Transfusion, v. 49, No. 2, p. 330-336, 2009.

Andrade, A. L. S. S.; Martelli, C. M. T.; Sousa, L.C.S.; Sousa, M. A.; Zicker, F. Soroprevalência e fatores de risco para sífilis em população carcerária de Goiás. Revista do Instituto de Medicina Tropical de São Paulo, v. 31, No. 3, p. 177-182, 1989.

Bassichetto, K. C.; Mesquita, F.; Zacaro, C.; Santos, E. A.; Oliveira, S. M.; Veras, M. A. S. M.; Bergamaschi, D. P. Perfil epidemiológico dos usuários de um Centro de Testagem e Aconselhamento para DST/HIV da Rede Municipal de São Paulo, com sorologia positiva para o HIV. Revista Brasileira de Epidemiologia, v. 7, No. 3, p. 302-310, 2004. 
Bonney, K. M. Promoting civic engagement with neglected tropical disease education. Brazilian Journal of Biological Sciences, v. 3, No. 5, p. 23-26, 2016. https://doi.org/ 10.21472 /bjbs.030502

Brasil. Boletim Epidemiológico de Sífilis 2012. 2012a. Available from: <http://www.aids.gov.br/system/tdf/pub/2 012/89/boletim_sifilis_2012_2.pdf>. Acessed on: Sept. 30, 2017.

Brasil. Portaria no 1.376, de 19 de novembro de 1993. Available from: <http://sna.saude.gov.br/legisla/legisla/hem o/GM_P1376_93hemo.doc>. Accessed on: Sept. 30, 2017.

Brasil. Resolução RDC no 343, de 13 de dezembro de 2002. Available from: <http://www.aeap.org.br/doc/resolucao_rdc _343_de_13_de_dezembro_de_2002.pdf>.

Accessed on: Sept. 30, 2017.

Brasil. Resolução RDC/ANVISA no 153, de 14 de junho de 2004. Determina o regulamento técnico para os procedimentos hemoterápicos, incluindo a coleta, o processamento, a testagem, o armazenamento, o transporte, o controle de qualidade e o uso humano de sangue, e se us componentes, obtidos do sangue venoso, do cordão umbilical, da placenta e da medula óssea. Available from: <http://www.saude. mg.gov.br/images/documentos/RES_153.pdf>. Accessed on: Sept. 30, 2017.

Brasil. Resolução CSN no 466, de 12 de dezembro de 2012. 2012b. Available from: <http://bvsms.saude.gov.br/bvs/saudelegis/ cns/2013/res0466_12_12_2012.html>.

Accessed on: Sept. 30, 2017.

Brêtas, J. R. S.; Ohara, C. V. S.; Jardim, D. P.; Muroya, R. L. Conhecimentos de adolescentes sobre Doenças Sexualmente Transmissíveis: subsídios para prevenção. Acta Paulista de Enfermagem, v. 22, No. 6, p. 786-792, 2009. https://doi.org/10.1590/S0103-

21002009000600010

Galatoire, P. S. A.; Rosso, J. A.; Sakae, T. M. Incidência de sífilis congênita nos estados do Brasil no período de 2007 a 2009. Revista Arquivos Catarinenses de Medicina, v. 41, No. 2, p. 26-32, 2012.

Habif, T. P. Dermatologia clínica: guia colorido para diagnóstico e tratamento. 5. ed. Rio de Janeiro: Elzevier, 2012.

Kumar, V.; Abbas, A. K.; Fausto, N. Robbins \& Cotran: bases patológicas das doenças. 8. ed. Rio de Janeiro: Elsevier, 2008.
Lins, C. D. M. Epidemiologia da sífilis gestacional e congênita no extremo setentrional da Amazônia. Boa Vista: UFRR, 2014. Available from: <http://www.bdtd. ufrr.br/tde_arquivos/6/TDE-2014-0714T120900Z-166/Publico/CynthiaDantas deMacedoLins.pdf>. Accessed on: Sept. 30, 2017.

Mohana, J. A vida sexual dos solteiros e casados. 3. ed. São Paulo: Loyola, 2002.

Oliveira, E. H.; Silva, F. L.; Silva, M. L. Perfil epidemiológico dos doadores de sangue infectados pelo vírus HTLV I/II, no Estado do Piauí. Revista Interdisciplinar, v. 8, No. 1, p. 149-156, 2015.

Oliveira, V. M.; Verdasca I. C.; Monteiro, M. C. Detecção de sífilis por ensaios de ELISA e VDRL em doadores de sangue do hemonúcleo de guarapuava, Estado do Paraná. Revista da Sociedade Brasileira de Medicina Tropical, v. 41, No. 4, p. 428-430, 2008.

Paula, I. A.; Guibu, I. A. (Org.). DST/AIDS e a rede básica: uma integração necessária. São Paulo: Secretaria Estadual Saúde, 2007.

Pereira, L. M. C. M. Perfil epidemiológico dos doadores de sangue da fundação HEMOPA em Belém-Pará, infectados pelo vírus da imunodeficiência humana. Belém: Universidade Federal do Pará, 2009. (Graduate dissertation).

Rodrigues, M. A. Soroprevalência de sífilis em doadores de sangue do Hemocentro de Goiás no período de 2002 a 2011. Anápolis: UNUCET, 2012. (Undergraduate monography).

Sáez-Alquézar, A.; Albiere, D.; Garrini, R. H. L.; Marques, W. P.; Lemos, E. A.; Alves, A. Desempenho de testes sorológicos para sífilis, treponêmicos (ELISA) e não treponêmicos (VDRL e RPR), na triagem sorológica para doadores de sangue: confirmação dos resultados por meio de três testes treponêmicos (FTA ABS, WB e TPHA). Revista de Patologia Tropical, v. 36, No. 3, p. 215-228, 2007.

Santos, V. C.; Anjos, K. F. Sífilis: uma realidade prevenível: sua erradicação, um desafio atual. Revista Saúde e Pesquisa, v. 2, No. 2, p. 257-263, 2009.

São Paulo. Definições de casos de agravos de notificação em DST/HIV/AIDS. São Paulo: Centro de Referência e Treinamento DST/AIDS, 2012a. (Guia de bolso). 
São Paulo. Manual prático de vigilância epidemiológica de DST/Aids. São Paulo: Coordenação de Vigilância em Saúde, 2012b.

Silva, S. F.; Verde, R. M. C. L.; Vieira, J. F. P. N.; Soares, L. F.; Nascimento, M. H.; Oliveira, E. H. HIV and viral hepatitis co-infection in pregnancy: an epidemiological, clinical and diagnostic review. Brazilian Journal of Biological Sciences, v. 4, No. 8, p. 345-354, 2017. https://doi.org/10.21472/bjbs.040813 Tavares, L. H. L. C.; Silva, O.; Paz, L. C.; Lopes, L. A. B.; Oliveira, M. L. C.; Macedo, L. M. L.; Geraldes, S. Monitoramento das ações próredução da transmissão vertical da sífilis na rede pública do Distrito Federal. Revista Oficial do Conselho Federal de Enfermagem, v. 3. No. 1, p. 29-35, 2012.

Tiago, Z. S.; Picoli, R. P.; Graeff, S. V.-B.; Cunha, R. V.; Arantes, R. Underreporting of gestational, congenital and acquired syphilis among indigenous peoples in Mato Grosso do Sul State, Brazil, 2011-2014. Epidemiologia e Serviços de Saúde, v. 26, o. 3, p. 503-512, $2017 . \quad$ https://doi.org/10.5123/s167949742017000300008 